\title{
Phytotests as tools for monitoring the bioremediation process of soil contaminated with diesel oil
}

\author{
Dorota WieczoreK *, Ewa KWapisz, Olga Marchut-MikoŁaJCZyK, StanisŁaW Bielecki \\ Institute of Technical Biochemistry, Technical University of Lodz, Łódź, Poland \\ *Corresponding author: dorotawieczorek200@interia.pl
}

\begin{abstract}
The aim of the study was to determine changes in phytotoxicity levels during bioremediation of soil contaminated with $5 \%(\mathrm{v} / \mathrm{w})$ diesel oil and find their correlation with the effectiveness of hydrocarbon degradation. Bioremediation trials were performed using a Gordonia alkanivorans $S 7$ strain. The clean-up process was enhanced through the addition of dried fungal enzymatic preparations obtained from fungi Phanerohaete chrysosporium and Aspergillus niger. After 110 days of bioremediation the decrease in soil pollution ranged between 68 and $77 \%$ depending on treatment conditions. Toxicological tests using marker plants revealed significant differences in the phytotoxicity levels of soil during bioremediation, depending on the treatment variant. The addition of an enzymatic fungal preparation to soil was found to accelerate the rate of contaminant degradation. The rate of hydrocarbon depletion in subsequent phases of the remediation process was found to be correlated with the phytotoxicity level. The obtained results provide evidence that phytotests can be useful tools for monitoring toxicity changes during bioremediation either mediated only by bacteria or additionally stimulated by fungal enzymatic preparations.
\end{abstract}

Key words: Phytotoxicity test, bioremediation, monitoring, diesel oil, fungal enzymatic preparations

\section{Introduction}

Crude oil and products of its processing are major sources of pollution of terrestrial and water environments causing their degradation in the industrialized regions of the world. The most common pollutant is diesel oil (Klimiuk and Łebkowska, 2005) which is harmful to the natural environment and living organisms because the toxic effects of diesel oil on organisms may appear after the MAC concentrations (maximum allowed concentration) of $5 \mathrm{mg} / \mathrm{l}$ and STEL (short-term elevated levels) of $50 \mathrm{mg} / \mathrm{l}$ have been exceeded. The oral toxicity of diesel oil is relatively low, with two studies reporting LD50 (lethal dose for fifty percent of test organisms studied) values of $7.5 \mathrm{~g} / \mathrm{kg}$ and $16 \mathrm{ml} / \mathrm{kg}$ in rats. Depending on the literature sources, diesel oil is considered a second or third category carcinogen (Chilcott, 2011). Particularly deleterious to human health are poly-aromatic hydrocarbons (PAHs) contained in diesel oil. Numerous epidemiological and toxicological studies have shown a clear relationship between exposure to these compounds and an increased risk of cancer (Alexandrine et al., 2000; Faustioni and Bernucci and Marinelli, 2000; Goldman et al., 2001; Perera et al., 2005; Wang S. et al., 2008). The mutagenic and carcinogenic effects of these compounds result from their metabolic transformations (e.g. conversion to epoxy derivatives) occurring in the human body and aimed at their elimination from the organism (Rybicki et al., 2004; Coccia et al. 2009).

Changes caused by the long term presence of hydrocarbons in soil are difficult to estimate because of the complexity of interactions and the lack of clearly defined research standards in this area. Processes of soil selfclean-up usually take a long time. Human intervention is needed in terms of both pollution prevention and the development of technologies accelerating the process of pollution removal. The clean-up of oiled areas is possible only when they are populated by metabolically active hydrocarbon-degrading microorganisms. The effectiveness of bioremediation depends on many factors, such as access to oxygen, water, biogenic elements, appropriate pH and temperature (Kaszycki and Kołoczek, 2000; Libudzisz and Kowal, 2000; Nowak, 2008, Kauppi, 2011). It is easier to ensure suitable bioremediation conditions than to control the toxic effect of hydrocarbons and their degradation intermediates during this process.

It is well known that most of the components of crude oil and its derivatives show a certain level of toxicity in 
relation to the diverse community of organisms in the complex ecosystem of soil. Diesel fuel contains many compounds that have different chemical structures and different degrees of susceptibility to biodegradation. For that reason, successful bioremediation, which should be a continuous process leading to the mineralization of these compounds, is sometimes difficult (Philips et al., 2000 ) because intermediate metabolites of hydrocarbon degradation may be more toxic than original pollutants. Numerous data indicate that the control of toxicity levels in the successive steps of the bioremediation process is an essential element of monitoring these processes. Accurate determination of the toxicity requires application of appropriate methods. Currently used tests usually involve single species with soil fauna and flora. However, toxicological data related to only one indicator are insufficient to assess the impact on the entire ecosystem of the complex mixture of compounds contained in crude oil. Interactions between oil components and microorganisms during bioremediation have not yet been fully understood and therefore a more sophisticated control of the clean-up process is necessary. Not only chemical (the level and composition of pollutants) and biological (microbial population studies) parameters, but also changes in toxicity (Namieśnik et al., 2003; Płaza et al., 2005; Girotti et al., 2008) should be monitored during bioremediation.

Bioassays used to monitor levels of toxic contaminants during bioremediation of soil contaminated with diesel oil include survival tests of such organisms as protozoa Spirostomum ambigum (Spirotox test), shellfish Heterocypris incngruens (Ostracodotoxkit F test) and the earthworm Eisenia fotedia (Dorn et al., 1999; Kyung and Kyoung, 2001). Also, bacterial enzyme assays such as Microtox ${ }^{\circledR}$ (Al-Mutairi et al., 2008) and LumiStox ${ }^{\circledR}$ and genotoxicity tests such as the Ames test (Beâkaert et al., 1999), SOS chromotest (Bombardier et al., 2001) and Vitotox ${ }^{\circledR}$ (Park and Que Hee, 2001) are used to monitor toxicity levels.

The very popular Microtox ${ }^{\circledR}$ test, which is probably the most commonly used bioindication test (Dorn and Salanitro, 2000), employs the luminescent bacteria $V_{i-}$ brio fisheri. The level of luminescence is strongly dependent on the concentration and toxicity of pollutants, which makes the analysis very easy (Al-Mutairi et al., 2008). However, tests conducted with selected "laboratory" microorganisms do not represent the effects of toxic pollutants on typical soil microflora, which in the vast majority is not culturable under laboratory conditions. To obtain more representative results, fast germinating plants typical of the given type of soil and climatic zone were also used as pollution biomarkers. The different sensitivity of various plant species to the same pollutant (at the same concentration) and the undoubted role of plants in soil bioremediation processes has resulted in the increasing use of plant-based tests in analytics. In the remediation of soil vegetation plays a very important role as well. Literature data indicate that bioremediation processes are the most efficient in the root zone. Today it is known that the presence of pollutants significantly affects not only the composition and abundance of microorganisms, but also plant growth. Diesel oil indirectly affects soil $\mathrm{pH}$ and levels of micronutrients and macronutrients in contaminated land. The presence of hydrocarbons in soil suppresses plant vegetation and thereby makes the clean-up processes less effective (Kyung et al., 2004; Wyszkowski and Ziółkowaka, 2009; Vwioko and Omamo, 2012).

The use of plants in the bioindication of soil contaminated with petroleum products makes it possible to obtain rapid and direct information about the level of toxicity during the process of degradation of petroleum compounds. In addition, these assays can also be carried out in situ and therefore plant-based tests can be used as the first indicators of the presence of toxic compounds. Most frequently used indicator plants are: Lemna minor, Lepidium sativum, Zea mays, Triticum aestivum, Avena sativa Lactuca sativa Raphanus dativus, Phaseulus vulgari, Sorghum bicolor, Brassica Campestri, and Oryza sativa (Juvonen et al., 2000; Maila and Cloete, 2002; Qi et al., 2008). The Phytotoxkit ${ }^{\mathrm{TM}}$ is also available on the market (MicroBioTests Inc., Mariakerke Gent, Belgium, Phytotoxkit, 2004). The latter test was used in this study to monitor changes in the level of toxicity of soil contaminated with diesel oil during bioremediation processes which were conducted using either only a selected bacterial strain or such a strain and additionally selected fungal enzyme preparations.

\section{Materials and methods}

\section{Bioremediation processes}

Bioremediation processes were conducted for 4 months in laboratory conditions using identical 21 glass vials 
containing $1.8 \mathrm{~kg}$ of soil contaminated with diesel oil $(5 \% \mathrm{v} / \mathrm{w})$.

Table 1. Physico-chemical and biological properties of the soil used in the experiments include

\begin{tabular}{l|c}
\hline Clay $(\%)(\leq 2 \mu \mathrm{m})$ & 14 \\
\hline Silt $(\%)(2-50 \mu \mathrm{m})$ & 18 \\
\hline Sand $(\%)(\geq 50 \mu \mathrm{m})$ & 62 \\
\hline Bulk density $\left(\mathrm{g} \cdot \mathrm{cm}^{-3}\right)$ & 1.52 \\
\hline $\mathrm{pH}(1: 3), \mathrm{H} 2 \mathrm{O}$ & 5.5 \\
\hline $\mathrm{EC}\left(\mathrm{mS} \cdot \mathrm{cm}^{-1}\right)$ & 0.62 \\
\hline $\mathrm{TOC}(\%)$ & 2.1 \\
\hline Total N $(\%)$ & 0.14 \\
\hline $\mathrm{C}: \mathrm{N}$ & $15: 1$ \\
\hline Avail. $\mathrm{P}\left(\mathrm{mg}^{-1} \mathrm{~kg}^{-1}\right)$ & $37.7 \pm 0.26$ \\
$\mathrm{Ca}\left(\mathrm{Cmol} \cdot \mathrm{kg}^{-1}\right)$ & $2.00 \pm 0.15$ \\
$\mathrm{Mg}\left(\mathrm{Cmol} \cdot \mathrm{kg}^{-1)}\right.$ & $1.00 \pm 0.10$ \\
$\mathrm{~K}\left(\mathrm{Cmol} \cdot \mathrm{kg}^{-1}\right)$ & $0.45 \pm 0.01$ \\
$\mathrm{Na}\left(\mathrm{Cmol} \cdot \mathrm{kg}^{-1}\right.$ & $0.11 \pm 0.01$ \\
$\mathrm{Al}{ }^{3+}\left(\mathrm{Cmol} \cdot \mathrm{kg}^{-1}\right)$ & $0.95 \pm 0.03$ \\
\hline
\end{tabular}

The soil was inoculated with a one-day liquid culture of Gordonia alkanivorans $S 7$ (the strain from the collection of the Institute of Technical Biochemistry, Technical University of Lodz). A proportion of the soil samples were additionally treated with fungal enzyme preparations obtained from Phanerochaete chrysosporium or Aspergillus niger. These preparations were produced by solid state cultures of these fungi in culture medium containing wheat bran, malt extract, minerals and diesel oil at a concentration of $0.5 \%(\mathrm{v} / \mathrm{v})$. On completion of the culture the medium overgrown with mycelium was ground mechanically; next, mycelium was de-fatted with acetone (washed three times) and dried. The resulting preparations were stored at $25^{\circ} \mathrm{C}$ in sealed containers.

\section{Conditions and control of bioremediation processes}

The parameters controlled during the 4 month-bioremediation processes were as follows: a) water content in the soil, which was maintained at $25 \%$ through the replenishment of evaporated water and b) mass of the soil, which was checked every 2-3 days. In addition, soil samples in the vials were supplemented once a week with $\mathrm{NH}_{4} \mathrm{Cl}$ (nitrogen source) in doses ensuring the maintenance of the $\mathrm{N}: \mathrm{C}$ ratio at $10: 1$.

The following four variants of bioremediation conditions were used: A - trial with diesel oil inoculated with $G$. alkanivorans $S 7$, B - trial with diesel oil inoculated with $G$. alkanivorans $S 7$ with the addition of an enzyme preparation from $A$. niger, $\mathrm{C}$ - trial with diesel oil inoculated with $G$. alkanivorans $S 7$ with the addition of a $P$. chrysosporium enzyme preparation. D - control trial - soil contaminated with diesel oil. Tests were performed in triplicate.

\section{Chemical analysis}

To determine the total degree of utilization of hydrocarbons, soil samples ( $10 \mathrm{~g}$ ) were subjected to a two-step treatment. First, the sample was sonicated for 2 hours and then subjected to 2 hours extraction with dichloromethane which was carried out in a Soxhlet apparatus. Resulting extracts were left until the solvent evaporated and the mass of the extracted hydrocarbons was determined gravimetrically. The results were used to calculate the decrease in total hydrocarbon content caused by the microorganisms. Additionally, GC analysis of hydrocarbons extracted from the soil was performed. Hydrocarbons extracted as described in section 2.3.1. were dissolved in $1 \mathrm{ml}$ of hexane. Gas chromatography of hydrocarbons was performed using a Hewlett-Packard gas chromatograph (model 5980) equipped with a DB1 capillary column $(30 \mathrm{~m} \times 0.53 \mathrm{~mm} \times 0.25 \mu \mathrm{m})$ and a flame - ionization detector (FID). The analysis conditions were: the solvent - hexane, helium as a carrier gas, injector temperature of $300^{\circ} \mathrm{C}, 1 \mu \mathrm{l}$ injection volume, temperature program: $60^{\circ} \mathrm{C} /$ increase by $4^{\circ} \mathrm{C}$ in $1 \mathrm{~min} / 260^{\circ} \mathrm{C}$, FID temperature of $260^{\circ} \mathrm{C}$.

\section{Biological assay}

Phytotoxkit - set for the germination and early plant growth testing. Assay plates were filled with $140 \mathrm{~g}$ $(90 \mathrm{ml})$ of tested soil and moistened with distilled water to $100 \%$ water capacity and covered with filter paper. Then, the test plant seeds (mustard - Sinapis alba, cress - Lepidium sativum, sorghum - Sorghum saccharatum) were applied at 10 pieces per plate. Assay plates were incubated vertically at $25^{\circ} \mathrm{C}$ for 3 days. The tests were carried out in triplicate for each bioremediation variant. These tests were conducted seven times, at two week intervals. The reaction of plants to the presence of hydrocarbons and toxic intermediates of their metabolism was determined based on the degree of the inhibition of seed germination and root growth. All measurements were done using an "Image Tools" analysis program. 


\section{Data analysis}

The percentage inhibition (1) of seed germination (GI) and root growth inhibition (RI) for the plants was calculated from the formula:

$$
\mathrm{GI} \text { or } \mathrm{RI}=\frac{A-B}{A} \times 100 \%
$$

where: $\mathrm{A}$ is the mean seed germination level or root length in the control soil; $\mathrm{B}$ is the mean seed germination level or root length in the test soil.

The effect of each bioremediation variant on GI and RI was analyzed using the Statistica 10.0 program. The relationships between the intensity of carbohydrate degradation in the bioremediation processes (residual hydrocarbon content) and phytotoxicity parameters were determined by correlation coefficient $r$ with Statistica 10. Significance was set at $p=0.05$.

\section{Results and discussion}

This study on the bioremediation of soil contaminated with diesel oil, which was treated either with a selected bacterial strain or additionally with selected fungal enzyme preparations, focused on toxicological aspects of the clean-up process.

The biological material used in the study included: bacterial strain $G$. alkanivorans S7, which was described earlier by Kwapisz et al., 2008 and Romanowska et al., 2010 and crude fungal enzyme preparations derived from strains of $A$. niger and $P$. chrysosporium containing, among others, esterases and oxidoreductases such as laccase. Diesel oil (at a relatively high concentration of $5 \% \mathrm{v} / \mathrm{w}$ ) was used as a pollutant because, according to the literature, it more adversely affects the soil environment than gasoline fuel. Diesel oil components were found to affect, to a greater extent, both concentrations of macronutrients and micronutrients and soil physicochemical properties (Siuta, 2003; Henner et al., 1999). Bacteriological tests and phytotests seemed to be most useful for monitoring the changes in the toxicity of soil purified of hydrocarbons. However, since bacteriological tests are time and labor consuming we recorded changes in soil toxicity during the bioremediation process by analyzing the growth of selected, fast germinating and pollution-sensitive plants. Particular attention was paid to the growth of roots which are most sensitive to toxins while seed germination is much less inhibited.
Preliminary experiments revealed that in both the reference soil and contaminated soil the number of seeds that did not germinate was comparable. Furthermore, it was noted that the germination of seeds alone did not guarantee further growth of plant roots. Recent literature data prove that germination-capacity is only slightly affected by petroleum substances, heavy metals or other pollutants (Baran and Jasiewicz, 2008; Baran et al., 2009; Oleszczuk, 2008). Based on the observations described above, it was decided that the inhibition of seed germination cannot be the principal criterion reflecting toxicity changes occurring during biological treatment of soil contaminated with diesel fuel. For this reason, the studies focused on the control of the percentage inhibition of root growth as a key factor affected by the presence of toxic compounds in soil.

Results of phytotests (preliminary experience - not presented in this work) provide evidence that during the whole bioremediation process the level of the inhibition of root growth depends on bioremediation conditions and the botanical origin of seeds used in experiments. In each of the tested variants of bioremediation conditions, most sensitive to the presence of toxic petroleum compounds were the sorghum seeds, and least sensitive were the mustard seeds. Contaminated soils are frequently populated by plant species displaying different sensitivities to petroleum compounds and, therefore, to obtain complete information on the changes in soil toxicity, it was decided to present the average results of the tests checking the degree of root growth inhibition obtained for all the indicator plants used in our experiments. These average data are considered a more suitable model of the toxicity changes taking place in a natural and complex ecosystem contaminated with petroleum compounds; better than the data obtained for only one plant species.

The results collected from the phytotest (MicroBioTests Inc., Mariakerke Gent, Belgium, Phytotoxykit, 2004), in which mustard, sorghum and cress plants were used as indicators of the effectiveness of treatment variants, are shown in Figures 1,2 and 3. The obtained average data show that immediately after soil contamination with diesel oil, the inhibition of root growth reached $66 \%$ in all bioremediation variants. On the $20^{\text {th }}$ day of the process mediated by the bacterial strain $G$. alkanivorans $S 7$ (variant A), the level of phytotoxicity was significantly lower (36\%) than the control sample for which this parameter decreased only to $60 \%$ (the latter value was main- 


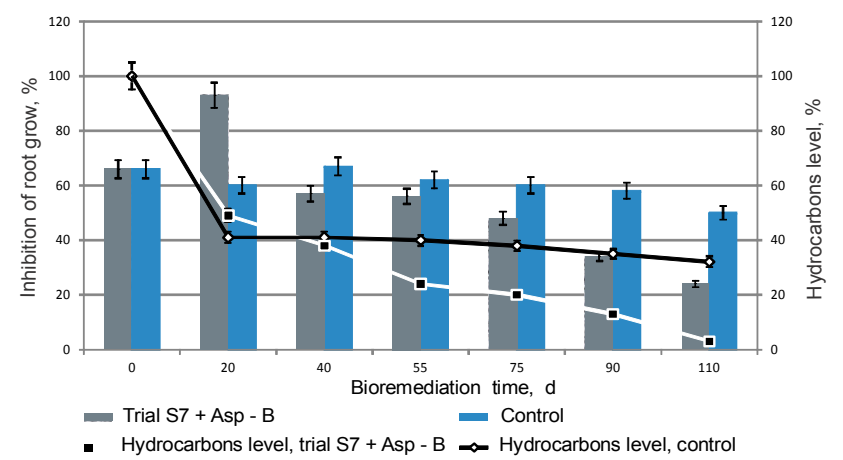

Fig. 1. Results of contaminated soil treatment using bacterium G. alkanivorans $S 7$ ( bioremediation variant A) - mean values \pm SD of percentage inhibition of root growth and residual hydrocarbon level $(n=3)$

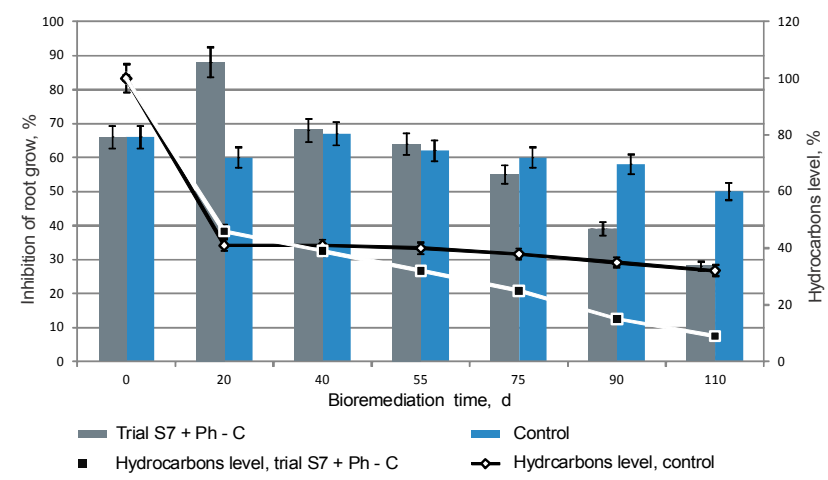

Fig. 2. Results of contaminated soil treatment using bacterium $G$. alkanivorans $S 7$ and enzyme preparation from $A$. niger (bioremediation variant B) - mean values \pm SD of percentage inhibition of root growth and residual hydrocarbon level $(n=3)$

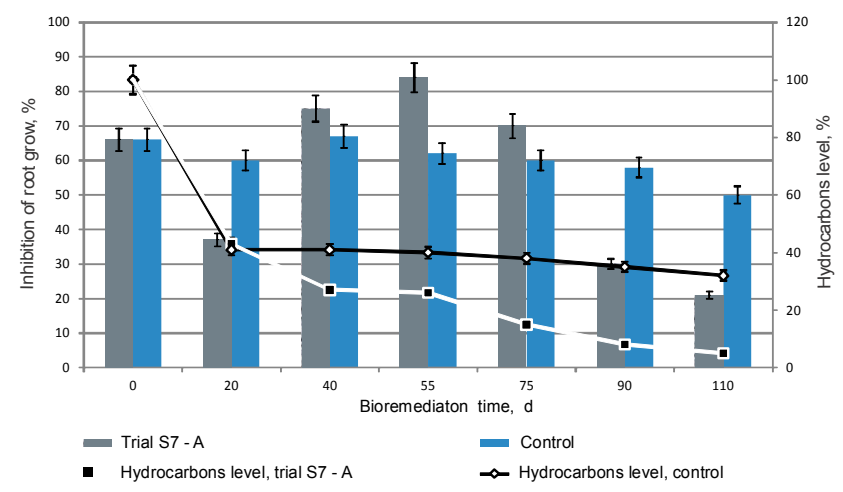

Fig. 3. Results of contaminated soil treatment using bacterium G. alkanivorans $S 7$ and enzyme preparation from $P$. chrysosporium (bioremediation variant $\mathrm{C}$ ). Phytotest results - mean values \pm SD of percentage inhibition of root growth and residual hydrocarbon level $(n=3)$

tained almost up to the $90^{\text {th }}$ day). As a comparison, in treatment variants involving fungal enzyme preparations (variants B, C) the inhibition of plant root growth in

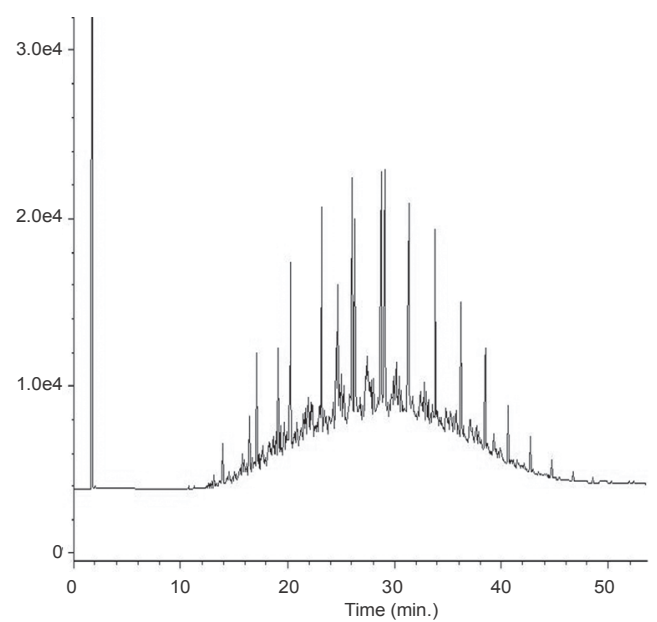

Fig. 4. GC profile of hydrocarbons and their intermediate metabolites produced by the $G$. alkanivorans $S 7$ strain (on the $75^{\text {th }}$ day of bioremediation)

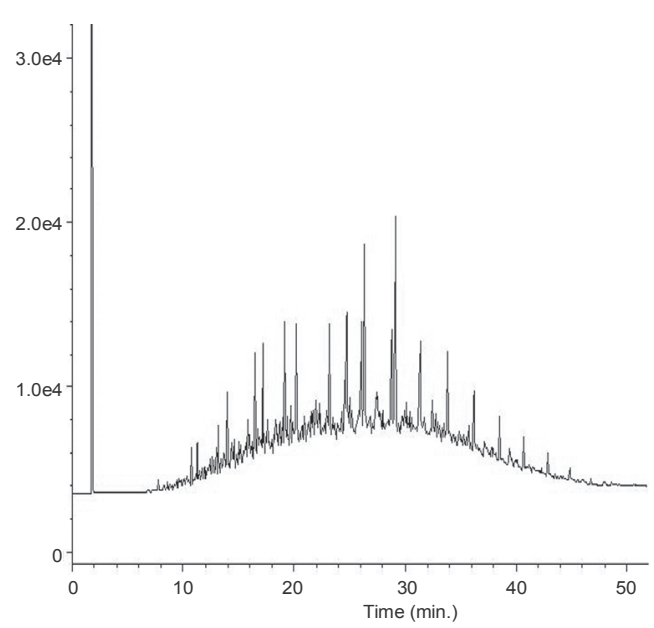

Fig. 5. GC profile of hydrocarbons and their intermediate metabolites produced by the $G$. alkanivorans $S 7$ strain assisted by the A. niger enzyme preparation (the on $75^{\text {th }}$ day of bioremediation)

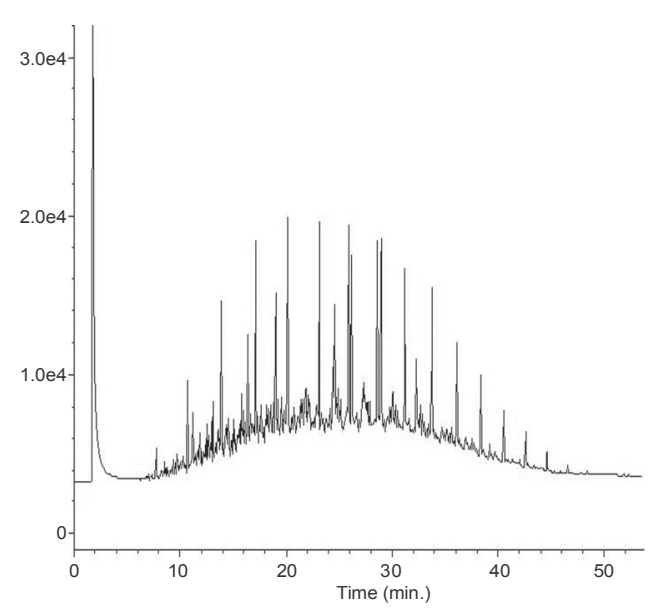

Fig. 6. GC profile of hydrocarbons and their intermediate metabolites produced by the $G$. alkanivorans $S 7$ strain assisted by the $P$. chrysosporium enzyme preparation (on the $75^{\text {th }}$ day of bioremediation) 
Table 2. Gas chromatography results for three repeated injections of the tested samples of hydrocarbons extracted from soil ${ }^{*}$

\begin{tabular}{|c|c|c|c|c|c|c|c|c|}
\hline \multirow{3}{*}{ Bioremediation, day } & \multicolumn{8}{|c|}{ Variants } \\
\hline & \multicolumn{2}{|c|}{$\mathrm{A}$} & \multicolumn{2}{|c|}{ B } & \multicolumn{2}{|c|}{$\mathrm{C}$} & \multicolumn{2}{|c|}{ Control } \\
\hline & $\begin{array}{l}\text { Number } \\
\text { of peaks }\end{array}$ & Total area & $\begin{array}{l}\text { Number } \\
\text { of peaks }\end{array}$ & Total area & $\begin{array}{l}\text { Number } \\
\text { of peaks }\end{array}$ & Total area & $\begin{array}{l}\text { Number } \\
\text { of peaks }\end{array}$ & Total area \\
\hline 0 & $\begin{array}{l}116 \\
120 \\
111\end{array}$ & $\begin{array}{l}0.48549 \times 10^{7} \\
0.49589 \times 10^{7} \\
0.47539 \times 10^{7}\end{array}$ & $\begin{array}{l}116 \\
120 \\
119\end{array}$ & $\begin{array}{l}0.48549 \times 10^{7} \\
0.49589 \times 10^{7} \\
0.47539 \times 10^{7}\end{array}$ & $\begin{array}{l}116 \\
120 \\
119\end{array}$ & $\begin{array}{l}0.48549 \times 10^{7} \\
0.49589 \times 10^{7} \\
0.47539 \times 10^{7}\end{array}$ & $\begin{array}{l}116 \\
120 \\
119\end{array}$ & $\begin{array}{l}0.48549 \times 10^{7} \\
0.49589 \times 10^{7} \\
0.47539 \times 10^{7}\end{array}$ \\
\hline 20 & $\begin{array}{l}103 \\
105 \\
102\end{array}$ & $\begin{array}{l}0.17644 \times 10^{7} \\
0.18544 \times 10^{7} \\
0.16999 \times 10^{7}\end{array}$ & $\begin{array}{l}106 \\
109 \\
104 \\
\end{array}$ & $\begin{array}{l}0.22055 \times 10^{7} \\
0.24005 \times 10^{7} \\
0.21457 \times 10^{7}\end{array}$ & $\begin{array}{l}101 \\
103 \\
105\end{array}$ & $\begin{array}{l}0.23762 \times 10^{7} \\
0.24967 \times 10^{7} \\
0.25744 \times 10^{7}\end{array}$ & $\begin{array}{l}97 \\
96 \\
99\end{array}$ & $\begin{array}{l}0.19733 \times 10^{7} \\
0.19001 \times 10^{7} \\
0.19899 \times 10^{7}\end{array}$ \\
\hline 40 & $\begin{array}{l}99 \\
98 \\
96 \\
\end{array}$ & $\begin{array}{l}0.15411 \times 10^{7} \\
0.15400 \times 10^{7} \\
0.14987 \times 10^{7}\end{array}$ & $\begin{array}{l}105 \\
104 \\
106 \\
\end{array}$ & $\begin{array}{l}0.17520 \times 10^{7} \\
0.17500 \times 10^{7} \\
0.16946 \times 10^{7}\end{array}$ & $\begin{array}{l}109 \\
110 \\
108 \\
\end{array}$ & $\begin{array}{l}0.21660 \times 10^{7} \\
0.22600 \times 10^{7} \\
0.22478 \times 10^{7}\end{array}$ & - & - \\
\hline 55 & $\begin{array}{l}92 \\
94 \\
96 \\
\end{array}$ & $\begin{array}{l}0.12113 \times 10^{7} \\
0.13169 \times 10^{7} \\
0.14123 \times 10^{7}\end{array}$ & $\begin{array}{l}112 \\
114 \\
110 \\
\end{array}$ & $\begin{array}{l}0.17510 \times 10^{7} \\
0.17988 \times 10^{7} \\
0.17354 \times 10^{7}\end{array}$ & $\begin{array}{l}102 \\
106 \\
105 \\
\end{array}$ & $\begin{array}{l}0.18688 \times 10^{7} \\
0.18933 \times 10^{7} \\
0.17987 \times 10^{7}\end{array}$ & - & - \\
\hline 75 & $\begin{array}{l}89 \\
88 \\
85 \\
\end{array}$ & $\begin{array}{l}0.08699 \times 10^{7} \\
0.08788 \times 10^{7} \\
0.07946 \times 10^{7}\end{array}$ & $\begin{array}{l}79 \\
84 \\
82 \\
\end{array}$ & $\begin{array}{c}0.16162 \times 10^{7} \\
016111 \times 10^{7} \\
0.17005 \times 10^{7}\end{array}$ & $\begin{array}{l}86 \\
87 \\
89 \\
\end{array}$ & $\begin{array}{l}0.11283 \times 10^{7} \\
0.12472 \times 10^{7} \\
0.13003 \times 10^{7}\end{array}$ & & - \\
\hline 90 & $\begin{array}{l}66 \\
57 \\
63\end{array}$ & $\begin{array}{l}0.07557 \times 10^{7} \\
0.07045 \times 10^{7} \\
0.08074 \times 10^{7}\end{array}$ & $\begin{array}{l}100 \\
103 \\
107\end{array}$ & $\begin{array}{l}0.13237 \times 10^{7} \\
0.14689 \times 10^{7} \\
0.15111 \times 10^{7}\end{array}$ & $\begin{array}{l}94 \\
95 \\
99\end{array}$ & $\begin{array}{l}0.09671 \times 10^{7} \\
0.09564 \times 10^{7} \\
0.10741 \times 10^{7}\end{array}$ & $\begin{array}{l}97 \\
94 \\
90\end{array}$ & $\begin{array}{l}0.17850 \times 10^{7} \\
0.18745 \times 10^{7} \\
0.16528 \times 10^{7}\end{array}$ \\
\hline
\end{tabular}

* variant A (treatment only with $G$. alkanivorans $S$ ), variant B (treatment with $G$. alkanivorans $S 7$ and an enzyme preparation from $A$. niger), variant C (treatment with $G$. alkanivorans $S 7$ and an enzyme preparation from $P$. chrysosporium), control - self-clean-up of soil contaminated with diesel oil ( $5 \% \mathrm{v} / \mathrm{v})$ 
creased to $90 \%$ on the $20^{\text {th }}$ day of the process. In the soil treated only with the $G$. alkanivorans $S 7$ strain, a similar phenomenon of a temporary increase in toxicity was observed later (up to $70 \%$ on the $40^{\text {th }}$ day and $80 \%$ on the $75^{\text {th }}$ day). These high toxicity levels suggest that the processes mediated by the selected bacterial strain and enhanced by enzymes contained in fungal preparations caused transient accumulation of toxic intermediate metabolites in the soil. However, neither structures nor concentrations of these hypothetic intermediates were determined in our study. It is noteworthy that up to the $20^{\text {th }}$ day of the clean-up processes the levels of residual hydrocarbons in all monitored soil samples (treatment variants A, B and C) were almost the same (46-51\%). In further steps of the bioremediation processes (between the $55^{\text {th }}$ and the $110^{\text {th }}$ day) the toxicity levels decreased: from $84 \%$ to $21 \%$ in variant $\mathrm{A}$, from $56 \%$ to $24 \%$ in variant $B$ and from $64 \%$ to $28 \%$ in variant $C$.

The experimental data provide evidence of a correlation between the phytotoxicity level and the rate of hydrocarbon biodegradation. In the second phase of bioremediation, a relatively high level of phytotoxicity and the slowest decrease in the content of petroleum substances, ranging between 1 and 4\%, were observed (the Pearson test correlation for the period between the $40^{\text {th }}$ and the $110^{\text {th }}$ day was strongly positive for each treatment variant, with factor $r$ values being: variant $\mathrm{A}-0.833$, variant $B-0.923$, variant $C-0.987$ ). After the $75^{\text {th }}$ day of bioremediation, when the toxic effects on plants were substantially weaker, the level of residual hydrocarbons was decreased and in the last phase of experiment it amounted to $5 \%, 3 \%$ and $9 \%$ of the initial hydrocarbon content for treatment variants $\mathrm{A}, \mathrm{B}$, and $\mathrm{C}$, respectively.

A GC analysis revealed that soil samples additionally treated with fungal enzyme preparations (variants $B$ and C) which were highly toxic to plants contained products of hydrocarbon metabolism (the increased number of peaks in the chromatograms of samples collected on days $55^{\text {th }}$ and $90^{\text {th }}$ for the treatment variant $\mathrm{B}$, and on days $40^{\text {th }}$ and $90^{\text {th }}$ for the treatment variant $C$ ). In the control soil sample and the sample processed according to treatment variant A (bioremediation was carried out using only $G$. alkanivorans $S 7$ ) this phenomenon was not observed. These results suggest a transient accumulation of toxic intermediate metabolites in the first soil samples and a correlation between the increased number of intermediates and the elevated phytotoxicity level.
It is noteworthy that the intensity of the degradation of different hydrocarbon fractions of diesel oil depended on the process mediator (cells of $G$. alkanivorans $S 7$ alone or additionally one of the two enzyme preparations) (Fig. 4, 5 and 6). The treatment of contaminated soil with the strain $G$. alkanivorans $S 7$ alone caused a relatively fast decrease in the content of short-chain hydrocarbons (Fig. 4). When the process also involved the enzyme preparation from $A$. niger, elimination of all hydrocarbon fractions was observed (Fig. 5). By contrast, when the bioremediation process was performed using both G. alkanivorans $S 7$ and $P$. chrysosporium enzyme preparations, long-chain hydrocarbons (longer than C14) were most quickly degraded (Fig. 6).

\section{Conclusions}

Bioremediation processes performed within the scope of the present study were strongly influenced by fungal enzyme preparations which were used apart from the selected bacterial strain. These enzyme preparations affected the biodegradation rates of hydrocarbon fractions and the levels of the accumulation of intermediate metabolites. The phytotoxicity test used in monitoring the processes is simple and inexpensive. This phytotest can be used for the assessment of toxicity in all phases of bioremediation of soil contaminated with diesel fuel. Our results suggest that there is a need to find other suitable plants that are common in our climate zone and display high sensitivity to different types of pollutants, in particular when the response depends on toxin concentration. Results of phytotests enable the selection of appropriate biological material to conduct bioremediation (microorganisms and/or enzyme preparations) and facilitate monitoring of clean-up processes. The results of our study provide evidence that phytotests are suitable bioindicators of the progress of land bioremediation, since they clearly show the transient increase in the phytotoxicity of treated soils. Conventional methods of soil quality assessment (standard chemical analysis of pollutants) during bioremediation may be insufficient in terms of the detection and quantification of toxic intermediate metabolites produced by microorganisms and enzymes involved in the clean-up process. Their concentrations may temporarily increase and considerably retard the process. Accumulation of pollutants and their toxic intermediate metabolites poses an additional threat to the 
natural environment. Therefore, quick toxicity tests are valuable tools minimizing such risks.

\section{References}

Alexandrie A.K., Warholm M., Carstensen U., Axmon A., Levin J.O., Ostman C., Rannung A. (2000) CYP1A1 and GSTM1 polymorphisms affect urinary 1-hydroxypyrene levels after PAH exposure. Carcinogenesis 21: 669-676.

Al-Mutairi N., Bufarsan A., Al-Rukaibi F. (2008) Ecorisk evaluation and treatability potential of soils contaminated with petroleum hydrocarbon-based fuels. Chemosphere 74: 142-148.

Baran A., Jasiewicz C. (2009) Toksyczna zawartość, cynku i kadmu w glebie dla różnych gatunków roślin. Ochr. Śr. Zasobów. Nat. 40: 157-164.

Baran A., Jasiewicz C., Klimek A. (2008) Reakcja roślin na toksyczną zawartość cynku i kadmu w glebie. Proc. EC Opole 2: 417-422.

Beâkaert C., Rast C., Ferrier V., Bispo A., Jourdain M.J., Vasseur P. (1999) Toxicity and genotoxicity of industrial soils polluted by polycyclic aromatic hydrocarbons (PAHS). Org. Geochem. 30: 953-962.

Bombardier M., Bermingham N., Legault R., Fouquet A. (2001) Evaluation of an SOS-Chromotest-based approach for the isolation and detection of sediment-associated genotoxins. Chemosphere 42: 931-944.

Coccia A.M., Gucci P.M.B., Lacchetti I., Beccaloni E., Paradiso R., Beccaloni M., Musmeci L. (2009) Hydrocarbon contaminated soil treated by bioremediation technology: microbiological and toxicological preliminary findings. Environ. Biotechnol. 5: 67-72.

Chilcott R.P. Compendium of chemical hazards: Diesel. Version 3. (2011) Available at: http://www.hpa.org.uk/ webc/...C/1194947407378. Access date: Jun. 10, 2012.

Dorn P.B., Vipond T.E., Salanitro J.P., Wisniewski H.L. (1999) Assessment of the acute toxicity of crude oils in soils using earth- worms, Microtox, and plants. Chemosphere. 5: 845860.

Dorn P.B., Salanitro J.P., (2000) Temporal ecological assessment of oil contaminated soils before and after bioremediation. Chemosphere 40: 419-426.

Girotti S., Ferri E.N., Fumo M.G., Maiolini E. (2008) Monitoring of environmental pollutants by bioluminescent bacteria. Anal. Chim. Acta 608: 2-29.

Goldman R., Enewold L., Pellizzari E., Beach J.B., Bowman E.D., Krishnan S.S., Hields. P.G. (2001) Smoking increases carcinogenic polycyclic aromatic hydrocarbons in human lung tissue. Cancer Res. 61: 6367-6371.

Henner P., Schiavona M., Druelleb V., Lichtfousea E. (1999) Use of an avoidance test for the assessment of microbial degradation of PAHs. Org. Geochem. 30: 963-969.

Juvonen R., Martikainen E., Schultz E., Joutti A., Ahtiainen J., Lehtokari M. (2000) A battery of toxicity tests as indicators of decontamination in composting oily waste. Ecotoxicol. Environ. Saf. 47:156-166.
Kaszycki P., Kołoczek H., (2000) Biotechnologie stosowane $w$ odnowie gleby zanieczyszczonej substancjami ropopochodnymi. Available at: http://fundacja.ogr.ar.krakow.pl/pdf/ Koloczek\%20Kaszycki\%20str\%2028-40.pdf Access date: Jun. 10, 2012.

Kauppi S. (2011) Bioremediation of diesel oil contaminated soil and water. Academic dissertation in Environ Ecology, University press Helsinki. 1-47, ISBN 978-952-10-7119-5. Available at: http://ethesis.helsinki.fi. Access date: Jun. $10,2012$.

Klimiuk E., Łebkowska M. (2005) Biotechnologia w Ochronie Środowiska. Wyd. PWN, Warszawa.

Kwapisz E., Wszelaka J., Marchut O., Bielecki S. (2008) The effect of nitrate and ammonium ions on kinetics of diesel oil degradation by Gordonia alkanivorans S7. Int. Biodeterior. Biodegrad. 61: 214-222.

Kyung H.B., Kyung. H.S., Hee-Mock O., Byung-Dae Y., Jaisoo K., In-Sook L. (2004) Effects of Crude Oil, Oil Components, and Bioremediation on Plant Growth. J. Environ. Sci. Health. Part A. 39: 2465-2472.

Kyung H.S., Kyoung W.K. (2001) Ecotoxicity monitoring of hydrocarbon-contaminated oil using earthworm (Eisenia foetida). Environ. Monit. Assess. 70: 93-103.

Libudzisz Z., Kowal K., (2000) Mikrobiologia techniczna. Wyd. Politech. Łódz., Łódź.

Maila M.P., Cloete T.E. (2002) Germination of Lepidium sativum as a method to evaluate polycyclic aromatic hydrocarbons (PAHS) removal from contaminated soil. Int. Biodeterior. Biodegrad. 50: 107-113.

Namieśnik J., Chrzanowski W., Szpinek A. (2003) Nowe horyzonty $i$ wyzwania $w$ analityce $i$ monitoringu środowiskowym. Wyd. CEEAM, Gdańsk.

Nowak J. (2008) Bioremediacja gleb $z$ ropy $i$ jej produktów Biotechnologia 80: 97-108.

Qi L., Kai-Li S., Hong-Mei Z., Weng-Hong L. (2008) Growth response of Zea mays $L$. in pyrene-copper co-contaminated soil and the fate of pollutants. J. Hazard Mater. 150: 515-521.

Park K., Que Hee S. (2001) Effect of Dust on the Viability of Vibrio fischeri in the Microtox Test. Ecotoxicol. Environ. Saf. 50: 189-195.

Perera, F., Tang D., Whyatt R., Lederman S.A., Jedrychowski W. (2005) DNA damage from polycyclic aromatic hydrocarbons measured by benzo[a]pyrene-DNA adducts in mothers and newborns from Northern Manhattan, the World Trade Center area, Poland, and China. Cancer Epidemiol. Biomarkers Prev. 14: 709- 714.

Philips T.M., Liu D., Seech A.G., Lee H., Trevors I.T. (2000) Monitoring bioremediation in creosote-contaminated soils Rusing chemical analysis and toxicity tests. J. Ind. Microbiol. Biotechnol. 24: 132-139.

Płaza G., Nałecz-Jawecki G., Ulfig K., Brigmon R.L. (2005) The application of bioassays as indicators or petroleumcontaminated soil remediation. Chemosphere. 59: 289296.

Romanowska I., Kwapisz E., Mitka M., Bielecki S. (2010) Isolation and preliminary characterization of a respiratory 
nitrate reductase from hydrocarbon-degrading bacterium Gordonia alkanivorans S7. J. Ind. Microbiol. Biotechnol. 37: 625-629.

Rybicki B.A., Rundle A.T., Sankey S.S., Tang D. (2004) Polycyclic Aromatic Hydrocarbon-DNA Adducts in Prostate Cancer. Cancer Res. 64: 8854- 8859.

Siuta J. (2003) Ekologiczne, technologiczne i prawne aspekty rekultywacji gruntów zanieczyszczonych produktami ropy naftowej. Inż. Ekologiczna. 8: 7-27.

Vwioko D.E., Omamo C.E. (2012) Assessing successive plant growth on petroleum hydrocarbon degradation in highly polluted soil augmented with wood ash. Intern. J. Appl. Sci. Technol. 2: 247-267.
Wang S., Chanock S., Tang D., Li Z., Jędrychowski W., Perera F. (2008) An assessment of interactions between PAH exposure and genetic polymorphisms on PAH-DNA adducts in African American, Dominican, and Caucasian Mothers and Newborns. Cancer Epidemiol. Biomarkers Prev. 17: 405-413.

Wyszkowski M., Ziółkowska A. (2009) Role of compost, bentonite and calcium oxide in restricting the effect of soil contamination with petrol and diesel oil on plants. Chemosphere 74: 860-865.

Ziółkowska A., Wyszkowski M. (2010) Toxicity of petroleum substances to microorganisms and plants. Ecol. Chem. Eng. S. 17(1): 73-82. 